Web Site: https://jutq.utq.edu.iq/index.php/main

Email: journal@jutq.utq.edu.iq

\title{
Histolopathological exploration \& Morphological changes of thyroid gland with Grave disease
}

Layla Alhasan

Department of Biology, College of Education for Pure

Sciences, University of Thi-Qar, Thi-Qar, Iraq

Email: layla@eps.utq.edu.iq

\begin{abstract}
This study aimed to explain the signification of histological features and determined the morphological changes of Grave disease. The study includes (8) normal as control group and (10) abnormal represented group as which suspected with Grave disease of thyroid glands have been obtained from Al-Hussein teaching hospital, all cases were females. Histological exam explain comparison of normal and abnormal of thyroid with that revealed dominant features which are hyperplasia in epithelial cell of follicular, highly infiltration of lymphocyte, irregular shape of large and medium follicles and formation of papillae within these follicles. Also colloid materials appeared pale in color and unfiltered to stroma of lobe due to the degeneration which occurred in epithelial cell of follicles. In addition, the study determined the morphological parameters of normal and Graves disease which involved diameter of follicles and epithelial cells heights measurements as well as the parameters attained $252,120,10 ; 650,420,70$ respectively $20,10,10 ; 60,40,10$ respectively. The study reported that there is a high significant differences between diameter of large and medium follicles measurement in control group in compare with.Grave disease group where as there is no significant difference between diameter of small follicles in control group and Graves disease group as well as the study provided the same significant differences for epithelial cells height of follicles. The study it is concluded that Grave disease associated with a histopathlogical in different degrees among patient.
\end{abstract}




\section{University of Thi-Qar Journal Vol. 13 No.4 DEC 2018 \\ Web Site: https://jutq.utq.edu.iq/index.php/main \\ Email: journal@jutq.utq.edu.iq}

Keywords: Grave disease, Morphological changes, Thyroid gland, Histological exploration.

\section{Introduction}

Thyroid gland is composed of follicles which have a large lumen and are lined with a simple columnar or cuboidal epithelium, in human (Difoire,1981) as well as in monkey .The low cuboidal shape of the follicular cells indicates that the cells are not producing secretory products during the active secretary cycle, these cells become taller in morphology (Gartner \& Hiatt,2006).However, the follicular cells which have a large a rounded nuclei and vesicular. The capsule of thyroid gland sends septa of connective tissue into substance of the gland, subdividing it into incomplete lobules, The lobules contained many follicles of varies sizes, each follicles was surrounded by slender connective tissue, which supports the follicles and brings blood vessels(Baccha,1993).The follicles vary in size, they are usually filled by colloid shrinks away from the follicular wall because of the reagent used in section preparation (Dellman,1993). As concerning of follicles size, previous study mentioned that small follicles were located mainly at periphery of the lobes, therefore follicles were classified in here size according to their in different measurements, the average of length and width of small follicles were 15.0-80_micrometer, middle follicles were 80.1-1750 micrometer and large follicles 175.1-615.0 micrometer (Jelinek et al.,2000).Robert Graves reported on his observations of a disease in 1835,characterized by violent and long continued palpitations in females associated with enlargement of the thyroid gland. Also, Grave disease is most common cause of endogenous hyperthyroidism; it is characterized by a triad of manifestations. Graves disease occurs primarily in younger adults, with a peak incidence between the ages 20 and 40 .Women are affected up to seven times more than man, an increased incidence of Graves disease occurs among family members of affected patients, with a 50\% concordance among identical twins. The occurrence of this disorder is strongly with the inheritance of human leukocyte antigen(HLA)-DR3.In generally, as definition to the Grave disease is an autoimmune disorder in 


\section{University of Thi-Qar Journal Vol. 13 No.4 DEC 2018 \\ Web Site: https://jutq.utq.edu.iq/index.php/main \\ Email: journal@jutq.utq.edu.iq}

which a variety of auto antibodies may be present in the serum. These include antibodies to the TSH receptor, thyroid peroxisomes, and thymoglobulin; of these ,the TSH receptor is the most critical auto antigen against which antibodies develop; the effects of the generated antibody vary depending on which TSH receptor epitope it is directed against(Wilson,1991,Robbins et al.,2003). Morphology, in the typical case of grave disease, the thyroid gland is diffusely enlarged because of the presence of diffuse hypertrophy and hyperplasia of thyroid follicular epithelial cells. The gland is usually smooth and soft, and its capsule is intact . Microscopically, the follicular epithelial cells in untreated cases are tall and columnar and are more crowded than usual. This crowding often results in the formation of small papillae, which project into the follicular lumen. Such papillae lack fibro vascular cores, in contrast to those of papillary carcinoma. The colloid within the follicular lumen is pale, with scalloped margins. Lymphoid infiltrates, consisting predominantly of T cells, with fewer B cells and mature plasma cells, are present throughout the interstitium; germinal centers are common. Preoperative therapy alters the morphology of the thyroid in graves disease. For example preoperative administration of iodine causes involution of the epithelium and the accumulation of colloid by administration, fibrosis of the gland was results (Robbins et.al. 2003, Yasuko et al., 2004). Objective of this study aims to explain the histopathology degrees of grave disease and correlation between parameter of Grave disease and control cases also to indicate the prognosis of Grave disease.

\section{Materials \&Methods}

The present study included two groups which first group consisted of (8) Patients with suspected Graves's disease that their thyroid glands were obtained from surgical operation room while thyroid glands of control were (10) cases which obtained from forensic medicine. All samples were taken from educational All-Hussein hospital. The study selected and focused on females only. The preparation or all samples of two study groups were performed to make the histological sectioning and routine 


\section{University of Thi-Qar Journal Vol. 13 No.4 DEC 2018 \\ Web Site: https://jutq.utq.edu.iq/index.php/main \\ Email: journal@jutq.utq.edu.iq}

stain (heamatoxyline and eosin) according to (Luna, 1968). Then comparison had been done between two study groups as well as determined biometric study to diameter follicles and height of epithelial follicular cells for both study groups by ocular lens micrometer. Statistical analysis ( $\mathrm{T}$ test) had been done between two groups by using $\mathrm{T}$ test according (Al-Mohammad et al., 1986), Photomorphic had been taken by digital camera.

\section{Results}

The present study included that histolopatholgical exploration and morphometric of thyroid gland with grave disease as well as comparison with control of thyroid gland. Thyroid gland with grave disease under went from incomplete capsule which was non typical capsule such as in control thyroid gland so as the septa between lobe of gland some time appeared thin or disappear. The lobes were enlargement as comparison with control group (Fig.1, 2). As concerning, follicles in different sizes and distribution lobe of gland. Large follicles appeared in peripheral area of lobe and few in number with single lobe. These follicles contained high amount and pale color of colloid material as comparison with control group, follicles had irregular around shape that result in formation of papillae which extended into the lumen of follicle. (Fig.3, 4). As well as the epithelial cells of follicles were showed a highly hyperplasia and they are flat to columnar cells shape which mean while medium follicles had a varies in size that some medium follicle appeared as large follicle and other appeared to small follicle. They had different size whatever they appeared slightly irregular around shape and due to colloid material filled whole follicle and darker in color than large follicle. Medium follicle more in number than large follicle (Fig.5, 6). Also these follicles were more close to the central area of the lobe of gland. Hyperplasia of cell follicles was and where the shape of cells was cuboidal. The number of these follicles usually was more than large follicles and colloid material was thicker than large follicles. The small follicles occupied the most of majority of lobe which distributed within different area of lobe. They have somewhat regular and rounded shape that completely full with 


\section{University of Thi-Qar Journal Vol. 13 No.4 DEC 2018 \\ Web Site: https://jutq.utq.edu.iq/index.php/main \\ Email: journal@jutq.utq.edu.iq}

colloid material which have affinity to dark stain. Their numbers were highest than medium and large follicles, No observed hyperplasia of epithelial cells of follicle (Fig.6). In generally highly infiltration of lymphocytes invasion the stroma of lobe of gland also can be occasionally observed large follicles under what from degeneration of epithelial cells so that the considerable colloid material infiltration within stroma of lobe (Fig.6). The data in table (1)showed determination of the means of diameter of different size of follicles (Large,Medium,Small) with Grave disease which were $6.5 \mathrm{~mm}, 4.2 \mathrm{~mm}$ and $0.7 \mathrm{~mm}$ on respective meanwhile in control groups, Also the comparison morphometric provided that the some measurements were $2.5 \mathrm{~mm}, 1.2 \mathrm{~mm}$ and $0.4 \mathrm{~mm}$ on respective. The high significant differences were report between both study groups for diameter of large and medium follicles where as there is no significant difference for diameter of small follicle between study groups. The study reported that the dimensions of height epithelial cells of different size of follicles for normal and abnormal cases which attained in control group on $20 \mathrm{~mm}, 180 \mathrm{~mm}$ and $10 \mathrm{~mm}$ as well as in Graves disease group ,the epithelial cells height were $60 \mathrm{~mm} .40 \mathrm{~mm}$ and $10 \mathrm{~mm}$ on respectively, However the study demonstrated that there is high significant differences between epithelial cells height of large follicles in control and Graves disease group as well as epithelial cells high of medium follicles where as there is no significant differences between epithelial cells height in small follicles of control and Graves' disease group. 


\section{University of Thi-Qar Journal Vol. 13 No.4 DEC 2018 \\ Web Site: https://jutq.utq.edu.iq/index.php/main \\ Email: journal@jutq.utq.edu.iq}



Fig (1): Showed normal thyroid gland with typical capsule (ca), clear concentration septa (s). (40 x). H\&E stain.

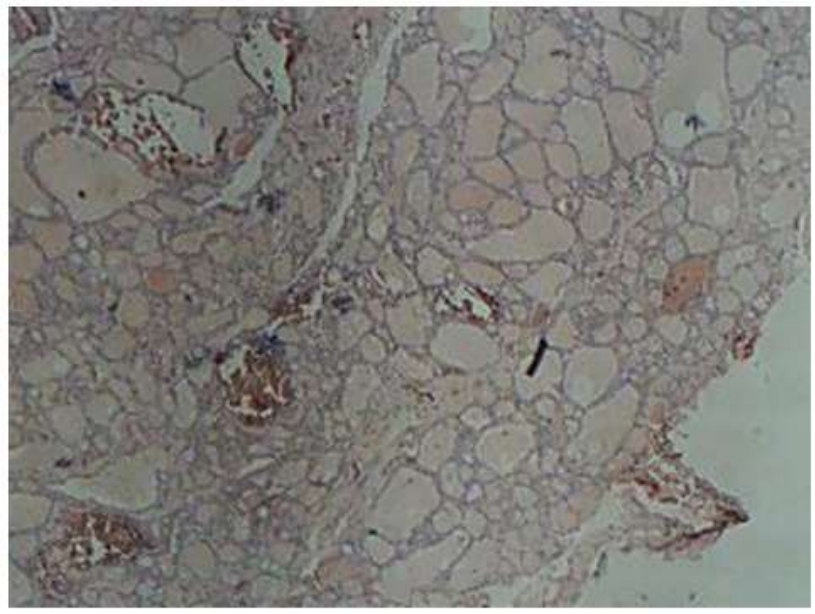

Fig :( 2): Showed thyroid gland and Grave disease characterized with non-typical capsule (ca) an disappeared of septa (s) between follicular lobes (40 x).H\&E staining 


\section{University of Thi-Qar Journal Vol. 13 No.4 DEC 2018 \\ Web Site: https://jutq.utq.edu.iq/index.php/main \\ Email: journal@jutq.utq.edu.iq}

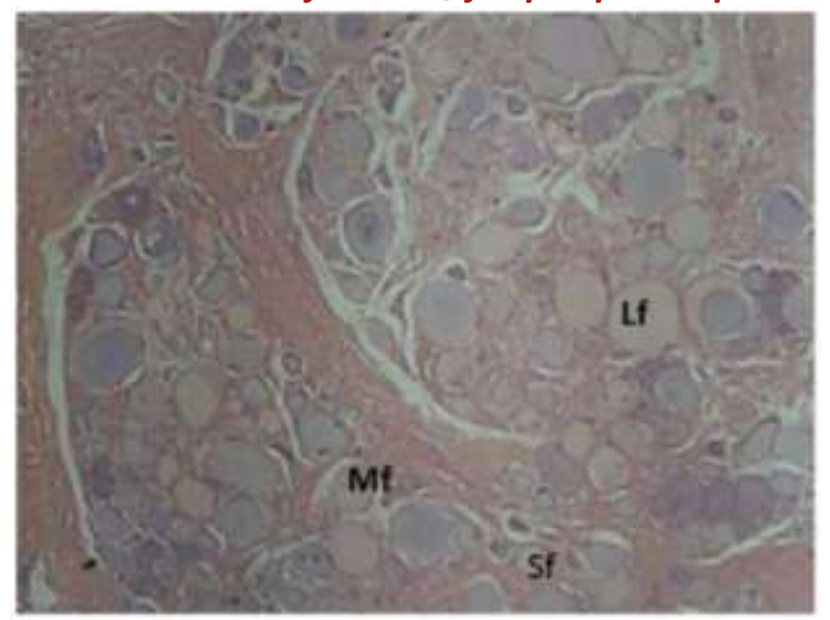

Fig( 3):Showed septa which separated between follicular lobes and regular different size of follicle(large,lf,medium,mf,small,sm) within each lobe (100x). H\&E stain.

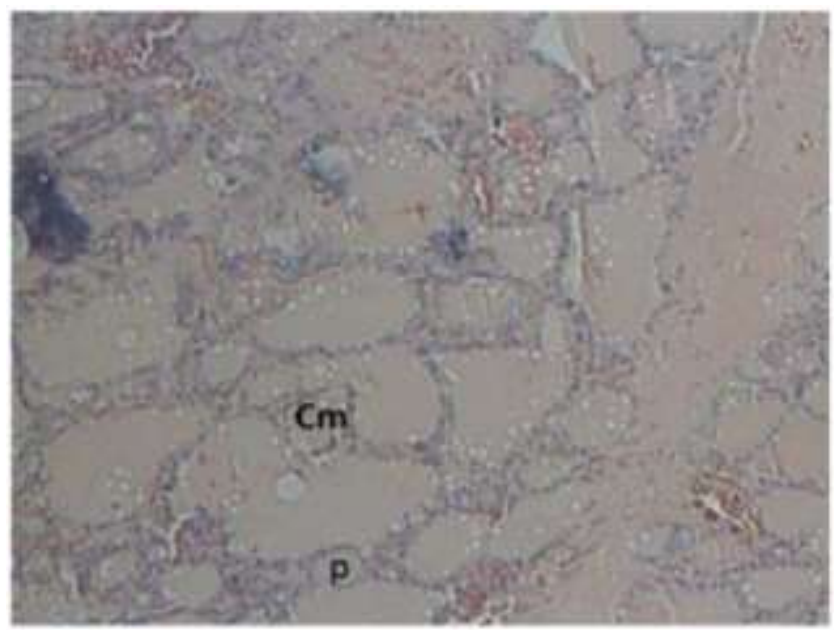

Fig (4): Showed histological changes of thyroid gland which appeared hyperplasia of epithelial cell of follicle and formation of papillae(p) which projected within follicle into lumen of follicle, colloid material $(\mathrm{cm})$ appeared as pale in color $(100 \mathrm{x})$. H\&E staining. 


\section{University of Thi-Qar Journal Vol. 13 No.4 DEC 2018 \\ Web Site: https://jutq.utq.edu.iq/index.php/main \\ Email: journal@jutq.utq.edu.iq}

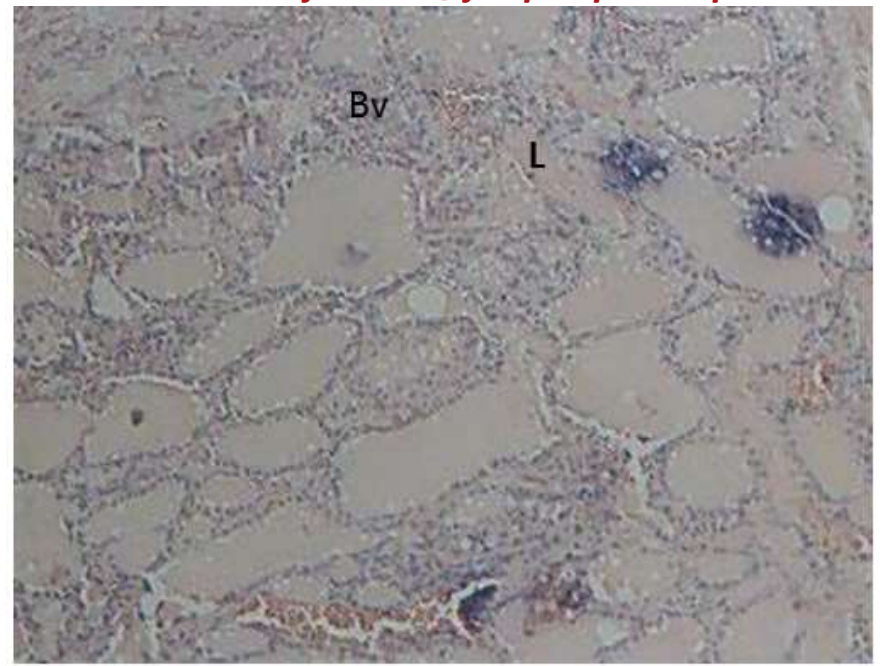

Fig (5): Showed histological changes of thyroid gland which appeared highly of invasion of lymphocyte (l) and degenerated of blood vessel (bv) also appeared different within stroma (100x). H\&E staining.

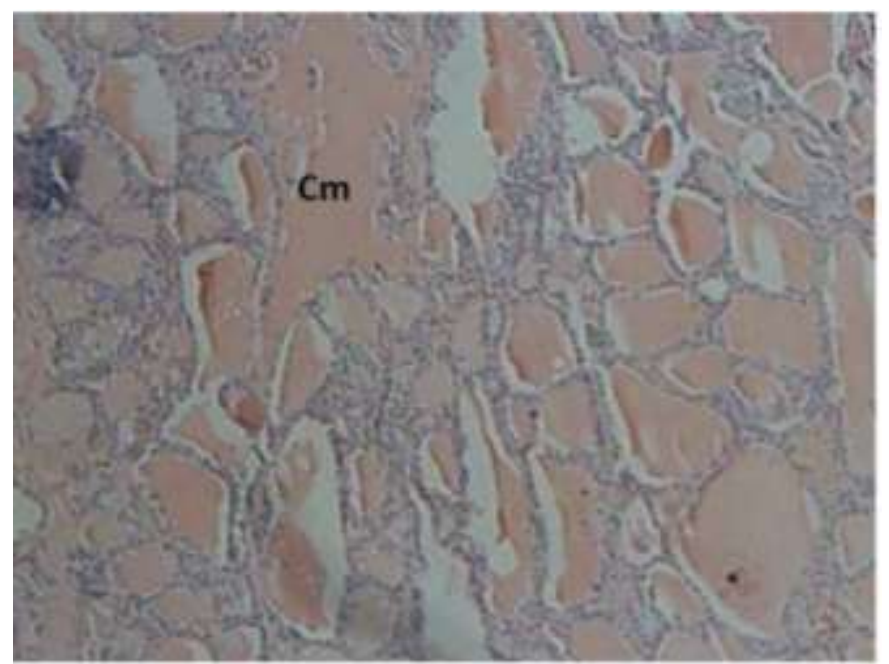

Fig (6): Showed histological changes of thyroid gland which appear degeneration of epithelial cells of large follicle therefore colloid material $(\mathrm{cm})$ was observed with highly infiltration within stroma(100x). H\&E stain. 


\title{
University of Thi-Qar Journal Vol. 13 No.4 DEC 2018 \\ Web Site: https://jutq.utq.edu.iq/index.php/main \\ Email: journal@jutq.utq.edu.iq
}

\begin{abstract}
Morphology parameters of thyroid gland with Graves's disease compared to control groups
\end{abstract}

\begin{tabular}{|c|c|c|c|c|}
\hline \multirow{2}{*}{$\begin{array}{c}\text { Size of } \\
\text { follicle }\end{array}$} & \multicolumn{2}{|c|}{$\begin{array}{c}\text { Morphology parameters of control } \\
\text { groups }\end{array}$} & $\begin{array}{c}\text { Morphology parameters of thyroid } \\
\text { gland with Graves' disease }\end{array}$ \\
\cline { 2 - 5 } & $\begin{array}{c}\text { The means of } \\
\text { height of } \\
\text { epithelial } \\
\text { follicular } \\
\text { cells/mm }\end{array}$ & $\begin{array}{c}\text { The means of } \\
\text { follicular } \\
\text { diameters/mm }\end{array}$ & $\begin{array}{c}\text { The means of } \\
\text { height of } \\
\text { epithelial } \\
\text { follicular } \\
\text { cells/mm }\end{array}$ & $\begin{array}{c}\text { The means of } \\
\text { follicular } \\
\text { diameters } / m m\end{array}$ \\
\hline $\begin{array}{c}\text { Large } \\
\text { follicles }\end{array}$ & $20 *$ & $252^{* *}$ & $60^{*}$ & $650^{* *}$ \\
\hline $\begin{array}{c}\text { Medium } \\
\text { follicles }\end{array}$ & $10^{*}$ & $120^{* *}$ & $40^{*}$ & $420^{* *}$ \\
\hline $\begin{array}{c}\text { Small } \\
\text { follicles }\end{array}$ & 10 & 40 & 10 & 70 \\
\hline
\end{tabular}

* referred to high significant difference between group $(\mathrm{P}>0.01)$

** referred to high significant difference between group $(\mathrm{P}>0.01)$

\section{Discussion}

The present stated that closely corresponding with previous histologipathological studies indicating that typical Graves disease characteristics with diffusely hyperplasia's the follicles are lined with tall, columnar epithelium and crowded enlargement epithelial cells project into the lumen of the follicles. These cells activity resorb the colloid in the centers of follicles, resulting the scalloped appearance of the colloid edges ( Cotran et al.,1994;Hikino et al.,1995 \&Koova et al.,1995) where as some cases of Grave disease in this study has been characterized with non typical histological features which provided Varity faces from case to case that attributed to Grave diseases occurred within many faces which have different symptoms (Michael et al.,1999) as well as combinations of multi-system manifestations vary widely from case to case ,and not all 


\section{University of Thi-Qar Journal Vol. 13 No.4 DEC 2018 \\ Web Site: https://jutq.utq.edu.iq/index.php/main \\ Email: journal@jutq.utq.edu.iq}

patients have classic symptoms initial examination, on symptoms or no sign may be clinically dominant as to observed other diagnostic finding(Nordyke et al.,1988,Haipeng,et al.,2002).The histological comparison between control and Grave disease cases pointed out that hyperplasia of epithelial cells $\mathrm{h}$ irregular shape of follicles and the pale color of colloid material in Grave disease which indicated the disorder was obviously affecting on function of thyroid gland to obtain early prognosis for Graves disease that was compatible as referring of microscopically description by (Braverman,1996) the shape of thyroid gland follicles has close relationship with their functional state ,thus the changes of its histological morphology can indicate its state of function, lined by single layer of follicles whose shape range from flattened to low columnar, with follicles enlarging, colloid plentiful and margin clear represents their inactive state, and active state when the epithelial columnar or bucking into follicles to form papillae (Haipeng et al.,2002). The considerable mention was closely associated and over lapping syndrome with Hashimotos disease and nontoxic goiter that especially in histopathological features were close similarity between them. According to (Robbins et al., 2002) described hashimotos disease that histological, was the thyroid parenchyma contain a dense lymphatic infiltration with germinal centers with residual thyroid follicles lined by eosinophilic cells. While nontoxic goiter morphology involved hypertrophy and hyperplasia of thyroid follicular cells, follicles crowded columnar cells, which may pile up and from projections similar to those in Grave disease ( Robbins, et al.,2002) in case of thyroid gland showed diffuse columnar epithelial hyperplasia (infolding) and colloid excess, with enlarging volume, this usually results in overt the goiter(Massart et al.,1991). The comparison of morphological parameters for two study groups provided Grave disease had higher dimensions than control group that the indication, The histological assessment of functional activity of the thyroid consist of estimation of size of the follicles, height of the follicular epithelium, quantity and color of colloid and proliferate activity of the epithelial cells.(Korova et al.,1998; Schorsch \& Pohlmayer-Esch et al.,2000, Serakides et al.,1999). 


\section{University of Thi-Qar Journal Vol. 13 No.4 DEC 2018 \\ Web Site: https://jutq.utq.edu.iq/index.php/main \\ Email: journal@jutq.utq.edu.iq}

\section{References}

1. Cha, W.J. \&Wood,M.(1990).Color Atlas of Veterinary Histology.Lea \& Febiger,Philadelphia,pp.178- 185.

2. Braverman, L.(1996).The different faces of thyrotoxicosis.Cleve. Clin. Med.; 63(5):259-261.

3. Delman, N.D.(1993).Textbook of Vterinary Histology. Four ed., Lea \&Febiger, Philadelphia .pp.280-282

4. Gartner, L.P. \& Hiatt, J.L (2006).Color Atlas Of Histology.4 ed., Lippincot Williams Wilkins Philadelphia, Pennsylvania.210-211. Philadelphia, 1400pp.

5.Haipeng,X.;Wenguan,Z.,Wang,Sh;Binjie,Yu.;Guorui,C.\& Wong ,N.C. 2002).Arterial Embolization:A Novel Approach to thyroid ablative therapy for Graves' disease .The J.Clin.Endo. \& Metabolism vol., 87.No. 83583, pp35-89.

Hikino,T,Fukushima,T,Saito,M.\&Hara,F.O.(1995).A simple silver stain for fungi using the sliver colloid solution for AgNoR stain Pathology International, 45:172-173.

7. Jelinek,F;Karbaava,I \& Kropova,V.(2003).Assessment of functional activity of the Bovine thyroid gland using morphometry and two markers of cellular proliferation.Acta Vet.Brno.,1-8. 8.Kovoa,M,Bekeova,E;Paure,T.\&Levkut,M.(1998).Height of the epithelial cells and diameter of follicles of the thyroid gland in lambs after long-termed intake of high and low doses of chlorine (In Slovak).In:Kice ,pp.45-49.

9-Luna, L.G. (1968).Manual of histologic staining methods of arme forces institute of pathology $3^{\text {rd }}$.New Yok,U.S.A.pp: 123.

10. Leslie, J.Degroot, M.D. (2002). Graves disease and the manifestations of thyrotoxicosis.European journal of the clinical nutrition .vol. 56.No.12.pp.1169-1175.

11. Massart, G, Guilhem, I.Gibassier, J.et al. (1991).Comparison of the thyroperxidase and microsomal antibody assays in sera from patents with Graves disease.Clin. Chem., 37(10):1777-1783. 12.Michael,W.Felz,MD.;Peter,P.\&Stein,MD.(1999).The many faces of Graves disease .J.Primary care physicians. Vol.,106 No.4.105-111pp. 


\section{University of Thi-Qar Journal Vol. 13 No.4 DEC 2018 \\ Web Site: https://jutq.utq.edu.iq/index.php/main \\ Email: journal@jutq.utq.edu.iq}

13. Nordyke, RA\&Gilbert,J.(1988).Graves disease :Influence of age on clinical findings.Arch.Intern. Med., 148(3):626-631.

14. Robbins, SL, Cotran, RS\&Kumar, V. (1994).Pathologic Basis of isease. Saunders.Phildelphia London ,889.

15. Schorsch, F, Pohlmeyer-Esch, G. (2001).Assessment of follicular cell proliferation in the rat thyroid gland: Propsal for double Immuno- staining procedure and Measure Strategy.Eur J .Vet. Pathol. 7:61-66. 16. Serakides, R.Nunes, VASantos, RL, Cassali, GD, Costa, N. (1999).Histomorphology and quantification of nucleolar organizer regions in Bovine thyroid containing methylthiouracil Residues .Vet .Pathol., 36:574-582.

17.المحد،،عيم ثاني،خاشع محمد الراوي، مؤيد يونس ووليد المار اني (1986) .مبادئ الإحصاء،مديرية

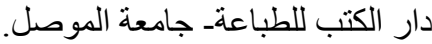




\section{University of Thi-Qar Journal Vol. 13 No.4 DEC 2018 Web Site: https://jutq.utq.edu.iq/index.php/main Email: journal@jutq.utq.edu.iq}

هدفت الدر اسه الحاليه الى در اسه التغيرات المظهريه و النسيجيه لمرض كريف. تضمنت الدر اسه 8 عينات غدد درقيه طبيعيه ( اناث) و 10 عينات غدد درقيه مرضيه (اناث) وتم جمع العينات

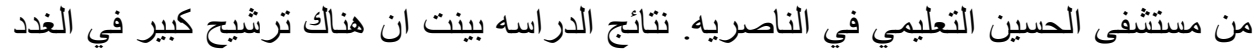

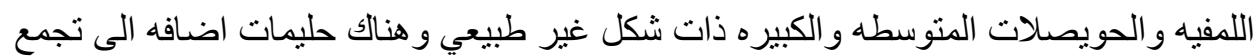
السوائل التي تكون بلون باهت بسبب تكسر في الخلايا الطلائيه. وقد تم دراسه اقطار الحويصلات لكلا المجمو عتين ( الطبيعيه و المرضيه). اوضحت نتائج الدراسه الحاليه فروقات معنويه بين الحويصلات المتوسطه والكبيره لمجاميع السيطره مقارنه بالمجاميع المرضيه وليس هناك تغير ات معنويه بالنسبه لاقطار الحويصلات الصغيره بين المجاميع السيطره ( الطبيعيه) و المرضيه. بلهيه ولهيه 